May I say that, though I have from time to time described emanation phenomena (Colonsay Mem., 1911, p. 29 ; Glen Coe Mem., 1915, pp. 112, 164 ; Mull Mem., 1924, pp. 167, 319), I have nowhere seen a more hopeful field of research in this respect than has been opened by Reynolds's disceveries at Slieve Gullion.

19 Greenhill Gardens,

E. B. BAILEY.

\title{
EDINBURGH.
}

18 th February, 1947.

\section{AGE RELATIONS OF CERTAIN GRANITES IN SKYE}

SIR,-In their letter in the Geological Magazine for JanuaryFebruary, 1947, Dr. Doris Reynolds and Mr. McIntyre discuss inter alia the relative age of certain rocks in Skye. Their opinion in this particular case seems to be summarized in a statement at the end of the sixth paragraph of their letter which reads as follows : " the Allt Daraich-Sron a'Bhealain sheet of marscoite is seen both to be chilled against the granophyre and to occur as inclusions within it." This statement assumes that the granophyre against which the marscoite is chilled is the same as the granophyre which contains the marscoite inclusions (Harker's spotted granophyre). Dr. Reynolds and Mr. McIntyre give no evidence to justify this assumption. In our view two granophyres of different ages are involved. One line of evidence on which we rely is the chilled contact to which we originally drew attention but it appears that for others such evidence has a different meaning.

The particular problem of the age of these Skye rocks cannot be discussed satisfactorily within the limits of a letter in this journal. We shall present a map and petrological account in due course.

J. E. RICHEY.

F. H. Stewart.

24th February, 1947.

L. R. WAGER. 